\title{
DOES CORPORATE SOCIAL RESPONSIBILITY ENHANCE RETURN ON ASSETS? EVIDENCE FROM MANUFACTURING FIRM IN NIGERIA
}

\author{
Nwankwo Carol \\ Department of Accountancy \\ Enugu State University of Science and Technology (ESUT) \\ Enugu, Nigeria \\ Onyeka Virginia Nnenna \\ Department of Accountancy \\ Enugu State University of Science and Technology (ESUT) \\ Enugu, Nigeria \\ And \\ Chukwuani Victoria Nnenna \\ Department of Accounting \\ Enugu State University of Science and Technology \\ Enugu, Nigeria
}

\begin{abstract}
The empirical research into the impact of CSR on return on assets is confusing and far from conclusive. Also in most of the previous studies; economic performance covered a (commonly five year) period "surrounding" the CSR performance and/or social disclosure periods. To overcome these limitations, our paper assess the impact of CSR return on assets of manufacturing firms in Nigeria. The result showed that with CSR, corporate social responsibility had a positive and significant effect on return on assets of the manufacturing organizations while without CSR, the impact is negative and non-significant. The implication is that what companies spend on the development of society of interest may be related to return on equity but does not significantly detect increase/decrease in return on equity. This study thus posits that manufacturing organizations should concentrate evenly also on other elements which organization see mainly as major determinants of return on assets as the finding is showing an insignificant effect of CSR on ROA.
\end{abstract}

Keywords: Corporate Social Responsibility, Return on Assets, Manufacturing Firms, Nigeria

\subsection{Introduction}

Since globalization surges on while technology continues to shift the foundations of economic reality at local, national, and international levels, ushering in new challenges to all firms and governments and blurring traditional distinctions among social institutions, it is critical to examine the notion of Corporate Social Responsibility (CSR). The EU's Green paper on Corporate Social Reporting defined it as 'a concept whereby companies integrate social and environmental concerns in their business operations and in their interaction with their stakeholders on a voluntary basis. And more recently, MC Williams and Siegel (2001) define it as actions that appear to further some social good, beyond the interests of the firm and that which is required by law. It could be traced back to such examples as the Quakers in 17th and 18th centuries whose business philosophy was not primarily driven by profit maximization but by the need to add value to the society at large - business was framed as part of the society and not separate from it.

The resurgent interest in the practice provides a fertile ground for different discourses and actors, which lends it to multiple and contested constructions (Moon 2002). Given the dominance of the West in shaping the CSR agenda, the contemporary CSR movement could be, arguably, said to be largely founded on Anglo-American priorities, philosophies and values (Kemp 2001; Fig, Chapple and Moon, 2005). And as typical of other business concepts, CSR is on its way to globalization, especially through Multinational Corporations (MNCs) and Multinational Institutions (MNIs). However, a central concern in the current drive for global CSR practice is the seeming underlying assumptions of the homogeneity of the CSR construct at a global level. In this regard, there is a burgeoning literature on the meaning and practice of CSR across cultures and national boundaries (Orpen, 1987; Langlois and Schlegelmilch, 1990; Bennett, 1998; Jones, 1999; Quazi and O'Brien, 2000; Maignan, 2001; Kusku and Zarkada-Fraser, 2004; Hamann et al., 2005;)

Since 1960s when CSR is initially mentioned, its nature has changed several times. Until now, the concept of CSR is also redefined and becomes a new definition. However, unlike the economic, legal and ethical expectations placed on organizations varies from societies to societies, all societies in the world at any period of their development have some similar expectations about what organizations should act under their social responsibilities. In the eighteenth century, the great economist and philosopher Adam Smith partly expressed the CSR in his economic research. He concluded that market participants must act honestly, a form of CSR, to reach the ideal situation of the free market. His theory was espoused by many new principles contributed by the Industrial Revolution in the nineteenth century, when many huge organizations were developed.

Those organizations, however, were not aware of the importance of CSR and did not act in a proper way for social welfare. Hence, in twentieth century, there is a backlash against the large corporations was appearance. They were criticized as being too powerful, creating monopoly markets and practicing socially irresponsible policies. Consequently, laws and regulations were enacted to regulate those large organizations, reduce their power and protect employees, consumers, and society. The labour movement also occurred to require a greater social responsibility in business activities. As a result of it, all businesses over the world began to gradually increase their social responsibilities further 
rather than pursuit the highest profit with impacts on social welfare. In the 1960s and 1970s the civil rights movement, consumerism, and environmentalism changed society's expectations about organizations' activities. They required the large organizations must have large responsibilities and contribute more to reduce social problems and engage in solving them.

Many governments issued legal mandates related to employees' rights, product safety, working condition and environmental protection. They were the first bricks to build up the modern concept of CSR today, which refers that corporations should aim towards the new goal above their current economic goal and legal responsibilities to contribute to the betterment of society. Human activity has impacted our physical environment in ways which stretch back before the dawn of civilization. The deliberate use of fire to clear land, for example, began tens of thousands of years ago. As human civilizations arose, so the impact of economic activity on local environments became an important issue. Deforestation and soil erosion caused the decline of many ancient cities and civilizations. By the time of the Greek and Roman empires, we can see new concerns arising about issues such as pollution and occupational health. With industrialization, concerns about localized environmental impacts gradually evolved into concern about the global environment.

During the Twentieth Century, this concern has developed into a debate about the sustainability of our economy and the societies and environment within which it exists. Also during the last century, we have witnessed the rise of global companies, and individual companies and their actions now feature prominently in discussions about the environment. "The phrase Corporate Social Responsibility was coined in 1953 with the publication of Bowen's Social Responsibility of Businessmen" (Corporate watch report, 2006). The evolution of CSR is as old as trade and business for any of corporation. Industrialization and impact of business on the society led to completely new vision. By 80's and 90's academic CSR was taken into discussion. The first company to implement CSR was Shell in 1998 (Corporate watch report (2006). With well informed and educated general people it has become threat to the corporate and CSR is the solution to it. In 1990, CSR as a standard industry with companies like Price Warterhouse Copper and KPMG. CSR evolved beyond code of conduct and reporting, it started taking initiative in NGO's, multi-stakeholder, ethical trading (Corporate watch report, 2006).

The empirical research into the impact of CSR on return on assets is confusing and far from conclusive. According to Ullmann (1985) this may be attributable to the use of varying and questionable measures of CSR, difference in research methodologies and the financial performance measures used. Also in most of the previous studies; economic performance covered a (commonly five year) period "surrounding" the CSR performance and/or social disclosure periods. To overcome these limitations, our paper assess the impact of CSR return on assets of manufacturing firms in Nigeria. The subsequent sections are divided into four. In section two, empirical literature were examined. In section three methodology adopted was explained. Section four presents our analysis and the paper concludes and recommended in section five.

\subsection{Literature Review}

Most researchers and scholars have a concrete believe that only a proven cause and effect relationship between CSR activities and financial performance can dramatically increase corporate social activity (Phillip \& Claus, 2002). Orlizky, et al. (2003) investigated corporate social responsibility and corporate financial performance by integrating 30 years of research from 52 previous studies by using Meta analytical techniques and the results confirmed a strong positive correlation between financial performance and the management of the company's social impact than financial performance with its environmental performance.

Tsoutsoura (2004) used extensive dataset which constitute most of the S\&P 500 firms over a period of five years (19962000) and explored the relationship between corporate social responsibility and financial performance measured using ROA; ROE and ROS as the dependent variables, while the independent variable was corporate social responsibility (CSR) of S \& $\mathrm{P}$ firms measured by KLD scores and tested by using empirical method which is found to be positively and statistically significant, supporting the view that socially responsible corporate performance can be associated with a series of bottom-line benefit.

Brine et al, (2006) observed the relationship between financial performance and corporate social responsibility across the total population of the top 300 Australian listed companies for the year 2005 financial year out of which 277 companies were drafted into the sample after dropping companies that did not meet the requirement. The study considered corporate social responsibility as the independent variable while financial performance as the dependent variable. The measurement was based on whether companies made separate sustainability disclosure beyond what is required of them by the regulatory frame work and the measurement of CSR was a dummy variable. The measurement used was ROA, ROE and ROS. The preliminary results revealed no statistical significant relationship exists between the adoption of corporate social responsibility and a firm's financial performance.

Saleh et al. (2007) found positive relationship between CSR actions disclosure and company performance in the short run. In a study conducted by Ajagbe, Adewoye and Ajetomobi (2007), in which the researchers evaluate financial performance of community banks by using a sample size of 8 community Banks, it is found that the response of the questionnaires and interviews that capital adequacy, liquidity reserve and cash reserve ratios were the significant factors in determining the performance of community Banks.

Fiori Donato, and Izzo, (2007) investigate the impact of voluntary disclosure of CSR on stock prices of Italian listed companies over the period of 2002-2007. The results show that the disclosure of CSR policies (especially those referred to employees) leads to higher stock prices because of the prevalence of a good perception of the market. 
Asongu (2007) looks at the history of corporate social responsibility and traced the historical roots of the concept of CSR from ancient times to modern day and finally concluded with the suggestion that more detailed study of the history of CSR needs to be conducted.

Vergalli and Poddi (2009) examined the effect of corporate social responsibility on performance of firms. The main results seem to have supported the idea that corporate social responsibility of firms has better long run performance. Even though it has some initial cost but obtain higher sales and profits due to several causes of reputation effect, and reduction of long run costs.

Ali, Rehman, Yilmaz, Nazir and Ali (2010) analyzed the behaviour of Pakistan consumers and find that the corporate social performance of producers does not motivate consumers to buy a product from cellular industry in Pakistan. Therefore, there is no significant relationship between awareness of CSR activities, consumer satisfaction, purchase intention, and consumer retention in Pakistan.

Babalola (2012) predicts three possible relations between CSR and company financial profitability. The first is neutral impact (such as Schröder, 2007). All companies, CSR complying as well as non- CSR complying, have the same rate of expected return and face the same cost of equity capital. This reasoning is in line with risk-return paradigm where only risk factors are priced in the market. The second is positive impact (such as Ziegler et al, 2007). If the risk associated to CSR compliance is correctly priced by the market, the same risk-return paradigm would imply a negative relation between CSR performance and financial performance. Companies which actively account for the CSR risk factor are seen as less risky investments relative to the companies that ignore it. The third view is negative impact (such as Wright \& Ferris, 1997). The compliance with CSR principles is not efficiently priced by market participants. A positive (negative) relation follows depending on the sign of the inefficiency as cited by Setiawan and Janet (2012).

Servaes and Tamayo (2012) investigated on the impact of corporate social responsibility on firm value based on the role of customer awareness. They found that corporate social responsibility (CSR) and firm value are positively related for firms with high customer awareness, as surrogated by advertising expenditures. For firms with low customer awareness, the relation is either negative or insignificant. In addition, they found that the effect of awareness on the value-CSR relation is reversed for firms with a poor prior reputation as corporate citizens. This evidence is consistent with the view that CSR activities can add value to the firm but only under certain conditions.

Wissink (2012) examined the relationship between corporate social performance and corporate financial performance. On the whole, the combined results suggested that the relationship between corporate social responsibility and corporate financial performance is at least neutral and perhaps slightly positive. However, the different approaches make it difficult to come to a final answer. But the result was put to the test once more, but only after trying to come to a more universal conceptualization and operationalization of the variables, based on the inclusion of Dow Jones Sustainability Index and Corporate financial performance was operationalized by means of three different accounting variables: ROA, ROE and ROS. The world's 2500 largest companies were assessed on general and industry specific sustainability criteria by means of self-report questionnaires, media- and stakeholder analysis, and data from secondary sources (company websites, annual reports, etc.). Instrumental stakeholder theory delineates a positive relation from CSP to CFP based on relations with stakeholders; CSR has a positive impact on a corporation's relationship with stakeholders, these improved relationships ultimately result in financial performance. Two hypotheses were tested by means of multivariate statistical tests. Based on the results of these tests, the following conclusions were drawn. Size and institutional context are determinants of corporate social performance (CSP); larger firms have a greater chance of being included in the DJSI, as do firms originating from Europe compared to those from North America. ROA and ROS are positively related to subsequent social performance, when firm size is appropriately controlled for, providing evidence of the slack resources theory. CSP is positively related to subsequent financial performance, providing evidence of the instrumental stakeholder theory. Taken together, the results provide evidence of a virtuous cycle of CSR. Better CFP results in better CSP and, in turn, better CSP results in better financial performance.

According to study conducted by Vitezić (2011), correlation exists between social responsibility and efficient performance of Croatian Enterprises. The initial point in the empirical section was dynamic analysis of business activities of Croatian entrepreneurs in the period between 1993 and 2010, on the basis of which a sample was chosen, which submit transparent reports on social responsibility. The main result obtained by univariate analysis confirms that socially more responsible enterprises have better financial results, i.e. they are more efficient, and also have better reputation. The conclusion is derived that there is a causal relationship between efficiency and social responsibility, i.e. higher efficiency level enables higher allocation of resources with the purpose of socially more responsible corporate performance and vice versa; socially responsible corporate performance have an impact on reputation and its improved efficiency.

Purnomo and Widianingsih (2012) conducted a research on the Influence of environmental performance on financial performance (with corporate social responsibility (CSR) disclosure as moderating variable) evidence from Listed Companies in Indonesia. They researched on the influence of environmental performance and Corporate Social Responsibility (CSR) Disclosure on financial performance have inconclusive results. This condition drives researcher to use CSR Disclosure as a moderating variable. The number of samples used in this research was ten firms in mining, chemical, pharmaceutical, cement, pulp and paper sectors which are listed on the Indonesia Stock Exchange (IDX) during 2006-2010 with 50 observations. Data are taken from annual report 2006-2010 of the companies listed on IDX by using multiple regression and moderated regression analysis. The CFP is measured using net profit margin, while environmental performance is measured using PROPER rating and CSR Disclosure is measured with CSR Index. The results indicate that environment performance has a positive effect on financial performance and CSR disclosure is not able to strengthen the influence of environmental performance on financial performance. 
According to Yang, Lin and Chang (2010), previous empirical studies have indicated an unclear relationship between CSR and financial performance, and literature has pointed out that innovation has a great impact upon CSP and CFP. Therefore, size and R\&D (research and development) are adopted in this study as control variables to investigate the relationship between CSP (Independent Variable), CFP (Dependent Variable) and CSP (Dependent Variable), CFP (Independent Variable) respectively. In this study, companies listed in the TSEC Taiwan 50 Index and TSEC Taiwan MidCap 100 Index was included as samples to analyze the linkage between CSP \& CFP, and by using regression analysis. The results pointed out that previous CSP has positive impact on the ROA for the next period; however, previous CFP has nothing to do with the latter CSP. In considering R\&D and size, the previous CSP has a positive correlation with the latter ROA. In addition, CSP has a negative correlation with ROE in the financial industry, and CSP has nothing to do with CFP in the electronic industry.

Setiawan and Janet (2012) examined Corporate Social Responsibility, Financial Performance, and Market Performance of consumer goods companies listed on the Indonesian Stock Exchange during the period 2007-2010. The analysis is completed by interviewing consumers, investors, and stock analysts from financial institution in Surabaya, Indonesia. The results of the study show that corporate social responsibility leads to increase in financial performance, but have no significant effect to market performance. Corporate social responsibility will build consumers" trust about the products and will encourage them to be loyal consumers. However, investor and stock analyst state that corporate social responsibility is a long term social investment that does not have a significant effect to the investment decision. In addition, most of the companies in the Indonesian consumer goods industry have a good financial performance, so that the stock prices remain constant.

Lungu, Chiraţa and Dascălu (2011) examined the relationship between reporting companies" characteristics and the importance assigned to social and environmental disclosure, by using statistical correlations based on content analysis of sustainability reports of the largest 50 companies classified by Global Fortune in 2009 in order to address the research hypotheses. The results show that size characteristics measured by assets and revenues cannot be correlated to the extent of CSR reports published by companies, but there is a significant negative correlation between change in revenues and return on equity and social and environmental disclosure for the sampled companies.

Keffas, and Olulu-Briggs (2011) examined the financial performance of CSR and Non-CSR banks using financial ratios and frontier efficiency analysis. They got accounting information for banks in Japan, US and UK quoted on the FTSE4 Good global index from Bank scope database. They include thirty-eight (38) financial and economic ratios based on variables such as Asset quality, Capital, Operations and Liquidity that captured major scope of financial performance. In addition, they used a non-parametric linear programming technique known as Data Envelopment Analysis to create a piecewise linear frontier that helps to determine the efficiency levels for both a common and separate frontier analysis. First, they find a positive relationship between corporate social responsibility and financial performance. Banks that incorporate CSR have better asset quality; capital adequacy, and are more efficient in managing their asset portfolios and capital. Second, they also find that geographical location regulates the relationship between CSR and FP during economic contraction, such that the relationship differs across the businesses and transactional banking models. The findings are to some extent consistent with prior analysis on the CSR-FP link.

Joe \& Kechi (2013) in their work titled, "Implications of Corporate Social Responsibility for the Performance of Nigerian Firms" recommended that firms should actively invest in proper waste management and pollution abatement, while social action should be approached with caution, and effective disclosure policies and practices put in place in order to avoid or eliminate liabilities of fines and penalties for environmental infractions.

\subsection{Methodology}

This paper adopted the ex-post facto design and data were sourced from financial statements and company's annual reports selected manufacturing firms in Nigeria for the period 2004 to 2013 . The population of our study is made up of 27 manufacturing companies listed on the Nigerian Stock Exchange. Each company in the population must have finished its obligation in delivering annual reports for the year ended 2013. However, a sample size of ten (10) listed manufacturing companies on the Nigerian Stock Exchange was randomly selected. With respect to the sample data, a non-probability sampling method was adopted.

Thus, 10 companies from 7 sectors (out of the 27 listed on the Nigerian Stock Exchange) were purposively selected. These sectors are, Breweries; Chemical and Paints; Conglomerate; Beverages; Health Care; Industrial/Domestic Products. Listed companies on the Nigerian Stock Exchange will be selected because of easier access to their annual reports as compared to the non-listed companies. The selected industries represented those that engage in Corporate Social Responsibility, which are either environmentally sensitive in their daily operations, or industrial and utility companies which are widely recognized to have the greatest social and environmental problems. These companies also represent those that engage in CSR reporting. Indigenous and multinational companies will also be included.

In the light of the aim of this paper, we state that there is no positive and significant impact of Corporate Social Responsibility reporting on return on assets of manufacturing organization in Nigeria, this is represented as:

$\mathrm{ROA}=\mathrm{F}(\mathrm{CSR})$

Model (i) can be further specified as: 
$\mathrm{ROA}=\mathrm{B} 0+\mathrm{B} 1(\mathrm{CSR})+\mathrm{U}$

where:

$\mathrm{ROA}=$ Return on Assets

CSR $=$ Corporate Social Responsibility

The simple regression analysis with the applications of the Ordinary Least Square (OLS) method was used to test the hypothesis.

\subsection{Analysis}

The hypothesis stated earlier in this paper were tested using regression method in this section. Three steps were used to test the hypothesis. In step one; the hypothesis was restated in null and alternate forms. In step two, both (with CSR and without CSR) results were analysed while in step three, decisions were made. The decision rule involved the rejection or acceptance of the null or alternate hypotheses based on criterion of the techniques of analysis.

\section{Test of Hypothesis}

Step One: Restatement of hypothesis in null and alternate forms.

Ho: $\quad$ There is no positive and significant effect of Corporate Social Responsibility reporting on Return on assets of manufacturing organization

$\mathrm{Hi}$ There is positive and significant effect of Corporate Social Responsibility reporting on Return on assets of manufacturing organization

Decision: Since the coefficient estimate of corporate social responsibility has a positive sign and its probability less than 0.05 , the null hypothesis is rejected and alternate hypothesis accepted. On the other hand, if the coefficient estimate of corporate social responsibility does not have a positive sign and its probability greater than 0.05 , the null hypothesis is accepted and alternate rejected.

\section{Step Two: Analysis of Result of Regression Results}

Table 1 Corporate social responsibility and Return on Equity (With CSR)

\begin{tabular}{|c|c|c|c|c|}
\hline \multicolumn{4}{|c|}{ Dependent Variable: ROE } & \\
\hline \multicolumn{5}{|c|}{ Method: Least Squares } \\
\hline \multicolumn{5}{|c|}{ Sample(adjusted): 2100} \\
\hline \multicolumn{5}{|c|}{ Included observations: 99 after adjusting endpoints } \\
\hline Variable & Coefficient & Std. Error & t-Statistic & Prob. \\
\hline CSR & 0.004710 & 0.005809 & 2.810839 & 0.0194 \\
\hline $\mathrm{C}$ & 0.075514 & 0.012250 & 6.164693 & 0.0000 \\
\hline R-squared & 0.566732 & Mean de & endent var & 0.082751 \\
\hline Adjusted R-squared & 0.453508 & S.D. dep & ndent var & 0.083332 \\
\hline S.E. of regression & 0.083478 & Akaike ir & o criterion & -2.108480 \\
\hline Sum squared resid & 0.675947 & Schwarz & riterion & -2.056053 \\
\hline Log likelihood & 106.3698 & F-statisti & & 0.657459 \\
\hline Durbin-Watson stat & 1.076316 & Prob(F-s & atistic) & 0.419443 \\
\hline
\end{tabular}

Source: Researcher's E-view Result

Table 1 above shows the result of the simple regression analysis of the effect of corporate social responsibility reporting on return on assets of manufacturing organization. The coefficient of determination (R-square), which measures the goodness of fit of the model, indicates that $57 \%$ of the variations observed in the dependent variable were explained by the independent variable. This was moderated to Adjusted R-squared to $45 \%$. The result shows that corporate social 
responsibility has a positive and significant impact on return on equity of the manufacturing organization when CSR is introduced $(a=0.00, p=0.01<0.05)$.

Decision: Since the coefficient estimate of corporate social responsibility is positive the null hypothesis is rejected and the alternate accepted but with the provision of probability value being greater than 0.05 we conclude therefore, that corporate social responsibility had a positive and insignificant effect on return on assets of the manufacturing organizations.

\section{Step Two: Analysis of Result of Regression Results}

Table 4.7 Corporate social responsibility and Return on Equity (With CSR)

\begin{tabular}{|c|c|c|c|c|}
\hline \multicolumn{5}{|c|}{ Dependent Variable: ROE } \\
\hline \multicolumn{5}{|c|}{ Method: Least Squares } \\
\hline \multicolumn{5}{|l|}{ Sample: 1100} \\
\hline \multicolumn{5}{|c|}{ Included observations: 100} \\
\hline Variable & Coefficient & Std. Error & t-Statistic & Prob. \\
\hline CSR & 0.008739 & 0.016672 & 0.524191 & 0.6013 \\
\hline C & 0.078874 & 0.011789 & 6.690407 & 0.0000 \\
\hline R-squared & 0.632796 & \multicolumn{2}{|c|}{ Mean dependent var } & 0.083244 \\
\hline $\begin{array}{l}\text { Adjusted R- } \\
\text { squared }\end{array}$ & 0.567380 & \multicolumn{2}{|c|}{ S.D. dependent var } & 0.083056 \\
\hline S.E. of regression & 0.083362 & \multicolumn{2}{|c|}{ Akaike info criterion } & -2.111459 \\
\hline Sum squared resid & 0.681018 & \multicolumn{2}{|c|}{ Schwarz criterion } & -2.059356 \\
\hline Log likelihood & 107.5730 & \multicolumn{2}{|c|}{ F-statistic } & 0.274776 \\
\hline Durbin-Watson stat & 1.078825 & \multicolumn{2}{|c|}{ Prob(F-statistic) } & 0.601329 \\
\hline
\end{tabular}

\section{Source: Researcher's E-view Result}

Table 2 above shows the result of the simple regression analysis of the effect of corporate social responsibility reporting on return on assets of manufacturing organization. The coefficient of determination (R-square), which measures the goodness of fit of the model, indicates that $63 \%$ of the variations observed in the dependent variable were explained by the independent variable. This was moderated to Adjusted R-squared to $56 \%$. The result shows that corporate social responsibility has a positive and non-significant impact on return on equity of the manufacturing organization when CSR is not introduced $(a=0.00, p=0.60<0.05)$.

Decision: Since the coefficient estimate of corporate social responsibility is positive the null hypothesis is rejected and the alternate accepted but with the provision of probability value being greater than 0.05 we conclude therefore, that corporate social responsibility had a positive and insignificant effect on return on equity of the manufacturing organizations when CSR is not introduced.

\subsection{Conclusion and Recommendations}

The result showed that with CSR, corporate social responsibility had a positive and significant effect on return on assets of the manufacturing organizations while without CSR, the impact is negative and non-significant. The implication is that what companies spend on the development of society of interest may be related to return on equity but does not significantly detect increase/decrease in return on equity. This result is in line with that of Brine et al (2006) in their study the relationship between financial performance and corporate social responsibility across the total population of the top 300 Australian listed companies. Whose result revealed that there is a statistical significant relationship between CRS and ROA. This study thus posits that manufacturing organizations should concentrate evenly also on other elements which organization see mainly as major determinants of return on assets as the finding is showing an insignificant effect of CSR on ROA. Manufacturing companies can increase their ROA by keeping asset cost down. This can be done by monitoring their asset expenses. For example, inventory counts as asset for the calculation of ROA. They should reduce inventory cost by managing the level of inventory to reflect sales expectation because excessive inventory can raise asset cost without producing more income. Manufacturing companies should also reduce equipment costs by renting or leasing 
equipment. This allows keeping only equipment needed when needed instead of buying a piece of equipment that may sit idle if needs change.

\section{References}

1. Ali, I. Rehman, K.U., Yilmaz, A.K., Nazir, S. \& Ali, J. F. (2010). "Effects of Corporate Social Responsibility on Consumer Retention in Cellular industry of Pakistan", African Journal of Business Management", vol. 4(4), pp. 475-485

2. Asongu, J. J. (2007). "The history of corporate social responsibility" journal of business and public policy volume 1, number 2

3. Babalola, Y. A. (2012). The impact of Corporate Social Responsibility on Firms profitability in Nigeria. European Journal of Economics, Finance and Administrative Science, 45(212), 41-50

4. Brine, M., R. Brown, and G. Hackett (2006). "Corporate social responsibility and financial performance in the Australian context ". Corporations and financial services Division, the Australian treasury

5. Corporate Social Performance and Identifying Measures for Assessing It Business \&

a. Dilemma Reston Publishing Co.:California, [accessed 2011]. Business Ethics

Quarterly, 4, 475, [accessed 2011]

6. Fiori, G. Donato, F. \& Izzo, M. F. (2007).Corporate Social Responsibility and Firms

a. Performance. An Analysis on Italian Listed Companies", $\quad$ http://ssrn.com/abstract=1032851 [accessed 20 June 2013].

7. Hillman, A. J., \&Keim, G. D. (2001). Shareholder value, stakeholder management, And social issues: What's the bottom line? StrategicManagementJournal, 22 (2): 125-139, [accessed 2011].

8. Keffas, G. And Olulu-Briggs, O. V. (2011). Corporate Social Responsibility: How Does It Affect the Financial Performance Of Banks? Empirical Evidence From Us, Uk And Japan Journal Of Management And Corporate Governance 2011 Cenresin Publications www.cenresin.org

9. Lungu, C. I., Caraiani, C. And Dascălu, C. (2011) research on corporate social responsibility reporting the Bucharest academy of economic studies, Romania 2011

10. Margolis, J. D. \& Walsh, J. P. (2001). "People and profits? The search for a link between a company's social and financial performance", Mahwah, $\mathrm{N} \mathrm{J}$ :Lawrence Erlbaum Associates.

11. McWilliams, A. \& Siegel, D. (2000). "Corporate social responsibility and financial performance: Correlation or misspecification?" Strategic Management Journal 21(5), 603-609.

12. Orlitzky, M., Schmidt, F. L. \& Rynes, S. L. (2003).Corporate Social and Financial Performance: A MetaAnalysis", Organization Studies 24(3), 403-441.

13. Purnomo, P. K. And Widianingsih, L. P. (2012). The Influence of Environmental Performance on

a. Financial Performance with Corporate Social Responsibility (CSR) Disclosure as a Moderating Variable: Evidence from Listed Companies in Indonesia Rev Integr Bus. Econ. Res. Vol 1(1) 57 Copyright $\angle 2012$ Society of Interdisciplinary Business Research (www.sibresearch.org)

14. Senaratne S. \& Wijesinghe K.N. (2011). Impact of Disclosure of Corporate Social Corporate Financial Performance in Bank, Finance and Insurance

a. Sector in Sri Lanka.

15. Setiawan, E \& Janet T J (2012). Corporate Social Responsibility, Financial Performance, and a. Market Performance: Evidence from Indonesian Consumer Goods Industry

16. Tsoutsoura, M. (2004). "Corporate social responsibility and financial performance" Applied a. financial project Haas school of Business University of California, Barkley

17. Vitezić, N. (2011), Correlation between social responsibility and efficient performance in Croatian enterprisesZb. rad. Ekon. fak.Rij. - 2011 - vol. 29 - sv. 2 - 423-442 423

18. Wissink, R. (2012). Testing the relation between corporate social performance and corporate

a. financial performance. Master thesis R.B.A Wissink University of Twente Business

b. Administration

19. Yang, F. Lin, C. and Chang, Y. (2010). The linkage between corporate social performance and

a. corporate financial performance African Journal of Business Management Vol. 4(4), Pp

b. 406-413, April 2010 Available online at http://www.academicjournals.org/AJBM ISSN

c. $1993-8233$ @ 2010 Academic Journals 